\title{
Morphometric and meristic characteristics of an endemic Lagusia micracanthus Bleeker, 1860 in the rivers of Maros and Walanae Cenranae Watersheds
}

[Karakteristik Morfometrik dan Meristik Ikan Endemik, Lagusia micracanthus Bleeker, 1860 pada Sungai-Sungai di Daerah Aliran Sungai (DAS) Maros dan DAS Walanae Cenranae]

\author{
Muhammad Nur ${ }^{1,2}$, M.Fadjar Rahardjo ${ }^{3}$, Charles P.H Simanjuntak ${ }^{3}$, \\ Djumanto $^{4)}$, Krismono 5 \\ ${ }^{1)}$ Doctoral Program, Graduated School of Aquatic Resources Management, IPB University \\ Jl. Lingkar Kampus IPB, Bogor 16680 \\ ${ }^{2)}$ Department of Fisheries, Sulawesi Barat University \\ J1. Prof Baharuddin Lopa, Majene, West Sulawesi 91412 \\ ${ }^{3)}$ Department of Aquatic Resources Management, IPB University \\ Jl. Lingkar Kampus IPB, Bogor 16680 \\ 4) Department of Fisheries, Faculty of Agriculture, Gadjah Mada University \\ Jl. Flora Gedung 4A, Bulaksumur Yogyakarta 55281 \\ ${ }^{5)}$ Research Center for Recovery of Fish Resources, Ministry of Marine Affairs and Fisheries \\ Jl. Cilalawi, Jatiluhur, Purwakarta, West Java 41152 \\ muhammadnur@unsulbar.ac.id,mf_rahardjo@yahoo.com,charles_phs@apps.ipb.ac.id, \\ lely4192@yahoo.com krismono2006@yahoo.com
}

Diterima: 2 April 2020; Disetujui: 9 Juni 2020

\begin{abstract}
Pirik (Lagusia micracanthus Bleeker, 1860) is one of endemic fishes in Sulawesi. Morphometric and meristic information of Pirik population in various habitats are unknown. The present study aimed to determine the morphometric and meristic variations of Pirik in Maros and Walanae Cenranae Watersheds. Sampling collection was carried out monthly from May 2018 to April 2019 in the Maros watershed, namely Pattunuang River (M1), Bantimurung River (M2), Pucak River (M3); and in Walanae Cenranae watershed particularly in Camba River (W1), Sanrego River (W2), and Ompo River (W3). Morphometric measurements consisted of 31 characters and meristic measurements consisted of 10 characters. Morphometric data was standardized by dividing all morphometric characters by standard length (SL). Analysis of variance (ANOVA) and discriminant analysis (Discriminant Function Analysis) were applied for data analysis. The results showed that the Pirik taken from rivers in the Maros and Walanae Cenranae watershed are two different population groups. There are 12 distinguishing morphometric features for Pirik of the Maros and Walanae Cenranae watershed, i.e. TL (total length), SL (standard length), BDdSA (body depth-dorsal fin origin), HL (head length), Jlup (upper-jaw length), PAfL (pre-anal fin length), ABL (Anal fin base length), PelRL (pelvic ray length), AFRL (anal fin ray length), CPL (caudal peduncle length), CLLup (upper caudal lobe length) and CLLmid (mid-caudal length). There is no significant difference of meristic characters of Pirik obtained from the Maros and Walanae Cenranae watersheds.
\end{abstract}

Keywords: morphometric, meristic, Lagusia micracanthus, Maros and Walanae Cenranae Watershed

\begin{abstract}
Abstrak
Ikan pirik (Lagusia micracanthus Bleeker, 1860) merupakan ikan endemik Sulawesi. Informasi morfometrik dan meristik untuk mengungkap perbedaan antar populasi L. micracanthus pada berbagai habitat belum pernah dilakukan. Penelitian ini bertujuan menganalisis perbedaan morfometrik dan meristik ikan pirik di Daerah Aliran Sungai (DAS) Maros dan DAS Walanae Cenranae. Manfaat penelitian ini adalah sebagai dasar dalam penentuan strategi konservasi dan pengelolaan ikan pirik secara berkelanjutan. Pengambilan sampel dilakukan pada bulan Mei 2018 hingga April 2019, di DAS Maros yang meliputi Sungai Pattunuang (M1), S.Bantimurung (M2), S.Pucak (M3) dan DAS Walanae Cenranae, yang meliputi S.Camba (W1), S.Sanrego (W2) dan S.Ompo (W3). Pengukuran morfometrik terdiri atas 31 karakter dan penghitungan meristik terdiri atas 10 karakterData morfometrik dibakukan dengan membagi semua karakter morfometrik dengan panjang standar (SL). Analisis data menggunakan analisis varian (ANOVA) dan analisis diskriminan (Discriminant Function Analysis). Hasil analisis menunjukkan bahwa ikan pirik yang berasal dari sungaisungai di DAS Maros dan DAS Walanae Cenranae merupakan dua kelompok populasi yang berbeda. Terdapat 12 karakter morfometrik yang menjadi penciri ikan pirik sungai-sungai di DAS Maros dan di DAS Walanae Cenranae yaitu TL (panjang total), SL (panjang baku), BDdSA (tinggi badan dari sirip punggung), HL (panjang kepala), Jlup (panjang rahang atas), PAfL (panjang sebelum sirip anal), ABL (panjang dasar sirip anal), PelRL (panjang sirip perut), AFRL (panjang jari-jari lemah sirip anal), CPL (panjang batang ekor), CLLup (panjang lobus ekor bagian atas), CLLmid (panjang tengah ekor). Karakter meristik antara ikan pirik di DAS Maros dan Walanae Cenranae tidak memiliki perbedaan yang nyata.
\end{abstract}

Kata penting: morfometrik, meristik, Lagusia micracanthus, DAS Maros, DAS Walanae Cenranae 


\section{Introduction}

Pirik (Lagusia micracanthus Bleeker, 1860) is one of the endemic fish species in Sulawesi (Vari 1978; Kottelat et al. 1993; Parenti 2011; Omar 2012; Vari \& Hadiaty 2012; Hadiaty 2018). This fish previously known as Datnia micracanthus, was first described in 1860 by Bleeker in the Lagusi River with a very limited sample number, three specimens only (Vari \& Hadiaty 2012). The scientific name of the Pirik was revised from Datnia micracanthus to Lagusia micracanthus based on phylogenetic analysis of fish from the Terapontidae family (Vari 1978). Many studies about Pirik L. micracanthus have documented the in the past 15 decades. Nonetheless, the sample size used in those studies was very small which leading to inadequate information on other aspects of the $L$. micracanthus species (Vari \& Hadiaty 2012).

Morphometric refer to quantitative analysis of fish body size, while meristic is features related to the number of fish body parts. Studies on morphometric and meristic have been carried out on various fish species due to its benefits including identification of fish species (Muchlisin 2013; Ukenye et al. 2019), fish populations differences (Palma \& Andrade 2002; Ahammad et al. 2018), migratory fish (Giducos et al. 2015), the male and female fish characteristics (Nath \& Kundu, 2017) and fish stock assessment (Turan et al. 2004; Mojekwu \& Anumudu 2015; Siddik et al. 2016). Morphometric and meristic currently become one of the most widely used information in fisheries management and conservation (Turan et al. 2005)

Studies on morphometric and meristic of $L$. micracanthus Pirik in various habitats have not been done yet. The basic morphometric and meristic information of $L$. micracanthus already been conducted (Vari \& Hadiaty 2012). However, the study was conducted in limited location. The present study aims to analyze the morphometric and meristic characteristics of $L$. micracanthus population from two different region in South Sulawesi, namely Maros and Walanae Cenranae watersheds. The information obtained from this study is expected to be useful in determining conservation strategies and sustainable management model of Pirik.

\section{Materials and methods}

Study sites

Fish sampling was conducted monthly from May 2018 to April 2019. Fish sampling was carried out at six locations, which consisted of three rivers in the Maros watershed, i.e. Pattunuang River (M1), Bantimurung River (M2) and Pucak River (M3) and three rivers in the Walanae Cenranae watershed namely Camba River (W1), Sanrego River (W2) and Ompo River (W3) (Figure 1).

\section{Sampling collection}

Sampling was carried out using a backpack electrofishing unit (12 V \& 9 A). Backpack electrofishing unit was operated in a zig-zag manner, against the current and operated for $200 \mathrm{~m}$, for 30 minutes. The fish caught was preserved in a $1000 \mathrm{ml}$ containing a $10 \%$ formalin solution. The samples were labeled based on the location, station and collection dates. After 24 hours, the fish specimens were rinsed with running water and transferred to containers containing $70 \%$ alcohol and then ready to be analyzed.

\section{Morphometric measurements and meristic counts}

Morphometric measurement and meristic counting of pirik (L. micracanthus) were carried out on 180 specimens, consisting of 90 specimens originating from the Maros watershed 


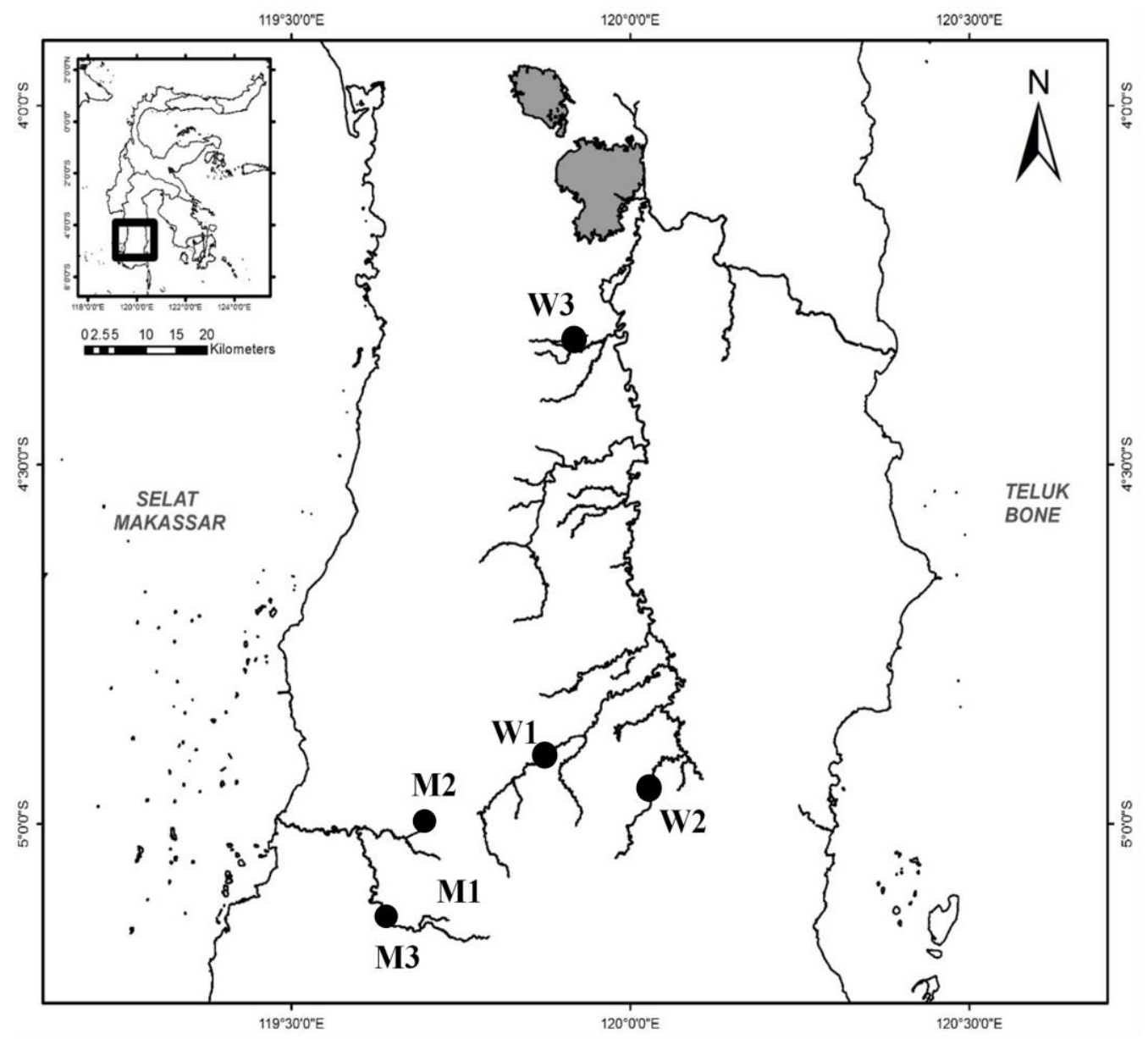

Figure 1. Map of sampling sites in two watersheds (the Maros Watershed and the Walanae Cenranae Watershed).

Annotation: M1 Pattunuang River, M2 Bantimurung River, M3 Pucak River, W1 Camba River, W2 Sanrego River, W3 Ompo River

(i.e. 30 individuals from M1 Patunuang R., 30 individuals from M2. Bantimurung R. and 30 individuals from Pucak R.) and the other 90 specimens were from the Walanae Cenranae watershed (i.e. 30 individuals from W1 Camba R., 30 individuals from W2 Sanrego R. and 30 speciemens from W3 Ompo R.). Morphometric measurement was carried out using $0.01 \mathrm{~mm}$ of digital calipers and meristic calculation was performed with the aid of a magnifying glass.

Morphometric character measurements and meristic counts refer to Vari (1978), Vari \&
Hutchins (1978), and Shelley et al. (2017) who conducted morphometric and meristic studies on freshwater Terapontid fishes. Additional calculations and other measurements refer to Hubbs \& Lagler (1974). In order to make comparisons, abbreviations were used to describe the character of the measurement. Morphometric measurements consisted of 31 characters (Figure $2 \&$ Table 1) and meristic counts consisted of 10 characters (Figure 3 and Table 2). 

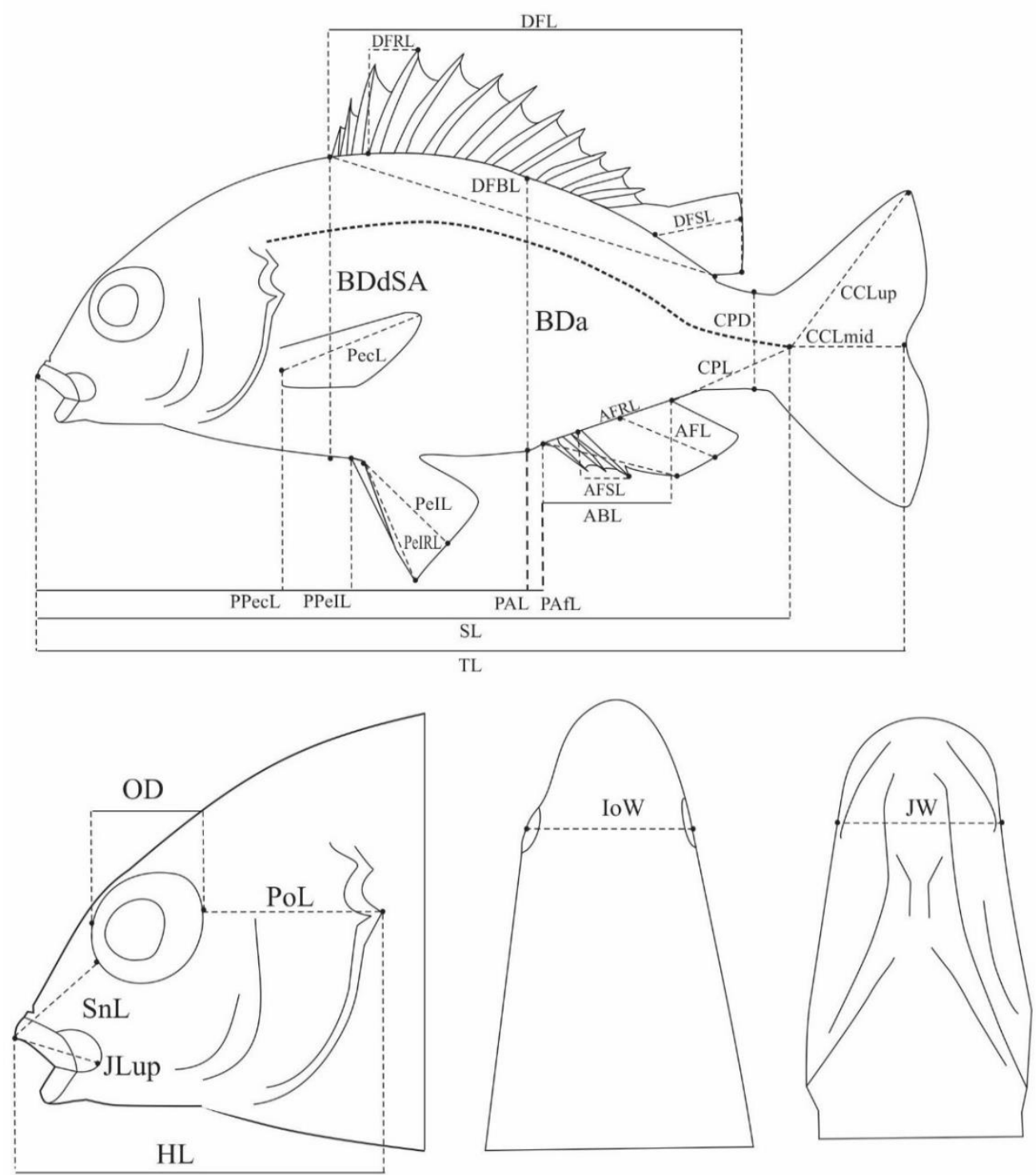

Figure 2. Morphometric characters of Pirik (Lagusia micracanthus Bleeker, 1860).

Annotation: TL (Total length), SL (Standard length), ABL (Anal fin base length), AFL (Anal fin length), AFRL (Anal fin ray length), AFSL (Anal fin spine length), Bda (Body depth-anal fin origin), BDdSA (Body depthdorsal fin origin), CLLmid (Mid-caudal length), CLLup (Upper caudal lobe length), CPD (Caudal peduncle depth), CPL (Caudal peduncle length), DFBL (Dorsal fin base length), DFL (Dorsal fin length), DFRL (Dorsal fin ray length), DFSL (Dorsal fin spine length), HL (Head length), IoW (Interorbital width), JW (Jaw width), OD (Orbital diameter), PAL (Pre-anus length), PAfL (Pre-anal fin length), PDFL (Pre-dorsal fin length), PelL (Pelvic fin length), PelRL (Pelvic ray length), PecL (Pectoral fin length), PoL (Postorbital length), PpelL (Pre-pelvic fin length), PpecL (Pre-pectoral fin length), PelSL, (Pelvic spine length), SnL (Snout length), Jlup (Upper-jaw length). 
Table 1 Description of morphometric characters

\begin{tabular}{|c|c|c|}
\hline Code & Character & Description \\
\hline TL & Total length & $\begin{array}{l}\text { The length from the tip of the snout to the tip of the } \\
\text { tail }\end{array}$ \\
\hline SL & Standard length & $\begin{array}{l}\text { The length from the tip of the snout to the base of } \\
\text { the hypural plate }\end{array}$ \\
\hline $\mathrm{ABL}$ & Anal fin base length & $\begin{array}{l}\text { The distance from the base of the first anal fin spine } \\
\text { to the posterior base of the last anal ray }\end{array}$ \\
\hline AFL & Anal fin length & $\begin{array}{l}\text { The distance from the base of the first anal fin spine } \\
\text { to the posterior-most margin of the anal fin }\end{array}$ \\
\hline AFRL & Anal fin ray length & $\begin{array}{l}\text { The length of the longest anal fin ray, from its base } \\
\text { to its tip }\end{array}$ \\
\hline AFSL & Anal fin spine length & $\begin{array}{l}\text { The length of the longest anal fin spine, from its } \\
\text { base to its tip }\end{array}$ \\
\hline $\mathrm{BDa}$ & Body depth-anal fin origin & $\begin{array}{l}\text { The vertical distance from the base of the anal fin to } \\
\text { the edge of the dorsal body margin }\end{array}$ \\
\hline BDdSA & Body depth-dorsal fin origin & $\begin{array}{l}\text { The length of the longest anal fin spine, from its } \\
\text { base to its tip }\end{array}$ \\
\hline CLLmid & Mid-caudal length & $\begin{array}{l}\text { The distance from the base of the caudal fin } \\
\text { (hypural plate) to the midpoint of the caudal fin's } \\
\text { outer margin. }\end{array}$ \\
\hline CLLup & Upper caudal lobe length & $\begin{array}{l}\text { The distance from base of the caudal fin (hypural } \\
\text { plate) to the outer-most margin of the upper caudal } \\
\text { fin }\end{array}$ \\
\hline CPD & Caudal peduncle depth & $\begin{array}{l}\text { The vertical distance from the dorsal margin to the } \\
\text { ventral margin, at the narrowest point on the caudal } \\
\text { peduncle }\end{array}$ \\
\hline CPL & Caudal peduncle length & $\begin{array}{l}\text { The distance between the posterior end of the anal } \\
\text { fin base to the base of the caudal fin }\end{array}$ \\
\hline DFBL & Dorsal fin base length & $\begin{array}{l}\text { The distance from the base of the first dorsal fin } \\
\text { spine to the posterior base of the last dorsal ray }\end{array}$ \\
\hline DFL & Dorsal fin length & $\begin{array}{l}\text { The distance from the base of the first dorsal fin } \\
\text { spine to the posteriormost margin of the dorsal fin }\end{array}$ \\
\hline DFRL & Dorsal fin ray length & $\begin{array}{l}\text { The length of the longest dorsal fin ray, from its } \\
\text { base to its tip }\end{array}$ \\
\hline DFSL & Dorsal fin spine length & $\begin{array}{l}\text { The length of the longest dorsal fin spine, from its } \\
\text { base to its tip }\end{array}$ \\
\hline HL & Head length & $\begin{array}{l}\text { The distance from the tip of the snout to the most } \\
\text { posterior point of the opercular margin }\end{array}$ \\
\hline IoW & Interorbital width & $\begin{array}{l}\text { The shortest distance between the edges of the or- } \\
\text { bits }\end{array}$ \\
\hline JW & Jaw width & $\begin{array}{l}\text { The distance between the posterior margins of the } \\
\text { jaw }\end{array}$ \\
\hline OD & Orbital diameter & The horizontal diameter of the orbit \\
\hline PAL & Pre-anus length & $\begin{array}{l}\text { The distance from the tip of the snout to the } \\
\text { anterior edge of the anus }\end{array}$ \\
\hline PAfL & Pre-anal fin length & $\begin{array}{l}\text { The distance from the tip of the snout to the base } \\
\text { of the anal fin }\end{array}$ \\
\hline
\end{tabular}


Table 1 (continued) Description of morphometric characters

\begin{tabular}{|c|c|c|}
\hline Code & Character & Description \\
\hline PDFL & Pre-dorsal fin length & $\begin{array}{l}\text { The distance from the tip of the snout to the base } \\
\text { of the dorsal fin }\end{array}$ \\
\hline PelL & Pelvic fin length & $\begin{array}{l}\text { The distance from the base of the pelvic fin spine } \\
\text { to the posterior-most margin of the pelvic fin }\end{array}$ \\
\hline PelRL & Pelvic ray length & $\begin{array}{l}\text { The length of the longest pelvic fin ray, from its } \\
\text { base to its tip }\end{array}$ \\
\hline PecL & Pectoral fin length & $\begin{array}{l}\text { The distance from the anterior base of the pectoral } \\
\text { fin to the posterior-most margin of the pectoral fin }\end{array}$ \\
\hline PoL & Postorbital length & $\begin{array}{l}\text { The distance from the posterior edge of the orbit to } \\
\text { the posterioro percular margin }\end{array}$ \\
\hline PPelL & Pre-pelvic fin length & $\begin{array}{l}\text { The distance from the tip of the snout to the base } \\
\text { of the pelvic fin }\end{array}$ \\
\hline PPecL & Pre-pectoral fin length & $\begin{array}{l}\text { The distance from the tip of the snout to the base } \\
\text { of the pectoral fin }\end{array}$ \\
\hline PelSL & Pelvic spine length & $\begin{array}{l}\text { The length of the pelvic fin spine, from its base to } \\
\text { its tip }\end{array}$ \\
\hline $\mathrm{SnL}$ & Snout length & $\begin{array}{l}\text { The distance from the anterior edge of the orbit to } \\
\text { the tip of the snout }\end{array}$ \\
\hline Jlup & Upper-jaw length & $\begin{array}{l}\text { The length from the tip of the snout to the base of } \\
\text { the hypural plate }\end{array}$ \\
\hline
\end{tabular}

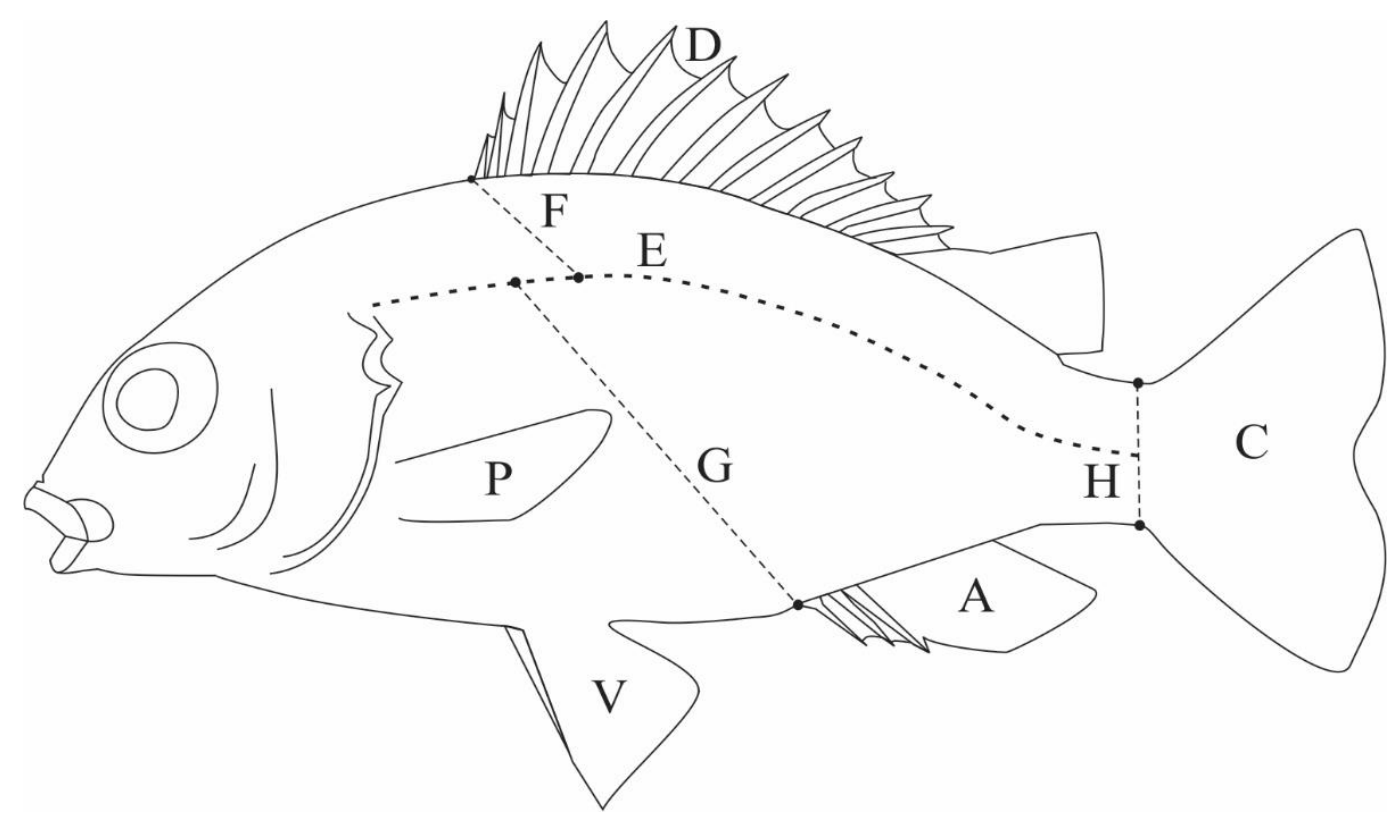

Figure 3. Meristic characters of Pirik (Lagusia micracanthus Bleeker, 1860).

Annotation : Dorsal fin spines and rays (D), Anal fin spines and rays (A), Caudal fin spines and rays (C), Ventral fin spines and rays (V), Pectoral fin spines and rays (P), Lateral line scale (E), Scale above lateral line (F), Scale below lateral line $(G)$, Scale on the caudal peduncle $(H)$. 
Table 2 Description of meristic characters

\begin{tabular}{cll}
\hline Code & \multicolumn{1}{c}{ Character } & \multicolumn{1}{c}{ Description } \\
\hline D & Dorsal fin spines and rays & The number of dorsal fin spines and rays \\
A & Anal fin spines and rays & The number of anal fin spines and rays \\
C & Caudal fin spines and rays & The number of caudal fin spines and rays \\
V & Ventral fin spines and rays & The number of ventral fin spines and rays \\
P & Pectoral fin spines and rays & The number of pectoral fin spines and rays \\
E & Lateral line scale & The number of scale rows from the lateral line to the anal \\
& & fin origin \\
F & Scale above lateral line & The number of scale above lateral line \\
G & Scale below lateral line & The number of scale below lateral line \\
H & Scale on the caudal peduncle & The number of scale on the caudal peduncle \\
\hline
\end{tabular}

\section{Data analysis}

Morphometric data of specimens was standardized by dividing all morphometric characters with standard length (SL). The Oneway ANOVA analysis of morphometric and meristic were applied for statistical analysis. Furthermore, fish morphometric and meristic were distinguished using Discriminant Function Analysis. Making dendrogram using expensive cluster analysis' distances that described the separation and relationship between the populations of fish being compared. Data analysis was carried out using SPSS (Statistical Program for Social Science) software version 26.0 .

\section{Results}

The Table 3 illustrates that a total of 31 morphometric characters was tested, and 27 morphometric characters were significantly different $(\mathrm{P}$ $<0.05)$ between Pirik population in Maros and Walanae Cenranae Watershed including TL (total length), SL (standard length), ABL (anal fin base length), AFL (anal fin length), AFRL (anal fin ray length), Bda (body depth-anal fin origin), BDdSA (body depth-dorsal fin origin), CLLmid (mid-caudal length), CLLup (upper caudal lobe length), CPD (caudal peduncle depth), CPL (caudal peduncle length), DFBL (dorsal fin base length), DFL (dorsal fin length), DFRL (dorsal fin ray length), DFSL (Dorsal fin spine length), HL (head length), JW (jaw width), PAL (pre-anus length), PafL (pre-anal fin length), PDFL (pre-dorsal fin length), PelRL (pelvic ray length), PecL (pectoral fin length), PoL (postorbital length), PpelL (pre-pelvic fin length), PpecL (pre-pectoral fin length), PelSL, (pelvic ray length) and Jlup (upper-jaw length). There were four characters that were not significantly different between two pirik population, namely AFSL (anal fin spine length), OD (orbital diameter), SnL (snout length) and IoW (interorbital width).

Stepwise analysis was carried out to determine the morphometric characteristics that characterize two populations of Pirik in Maros and Walanae Cenranae watersheds (Table 4). The results showed that there are 12 morphometric characters that characterize or differentiate groups of Pirik in Maros and Walanae Cenranae watersheds, for instances BDdSA (body depthdorsal fin origin), PelRL (pelvic ray length), CLLup (upper caudal lobe length), SL (standard length), AFRL (anal fin ray length), Jlup (upperjaw length), CPL (caudal peduncle length), PAfL (pre-anal fin length), TL (total length), ABL (Anal fin base length), HL (head length) and CLLmid (mid-caudal length). 


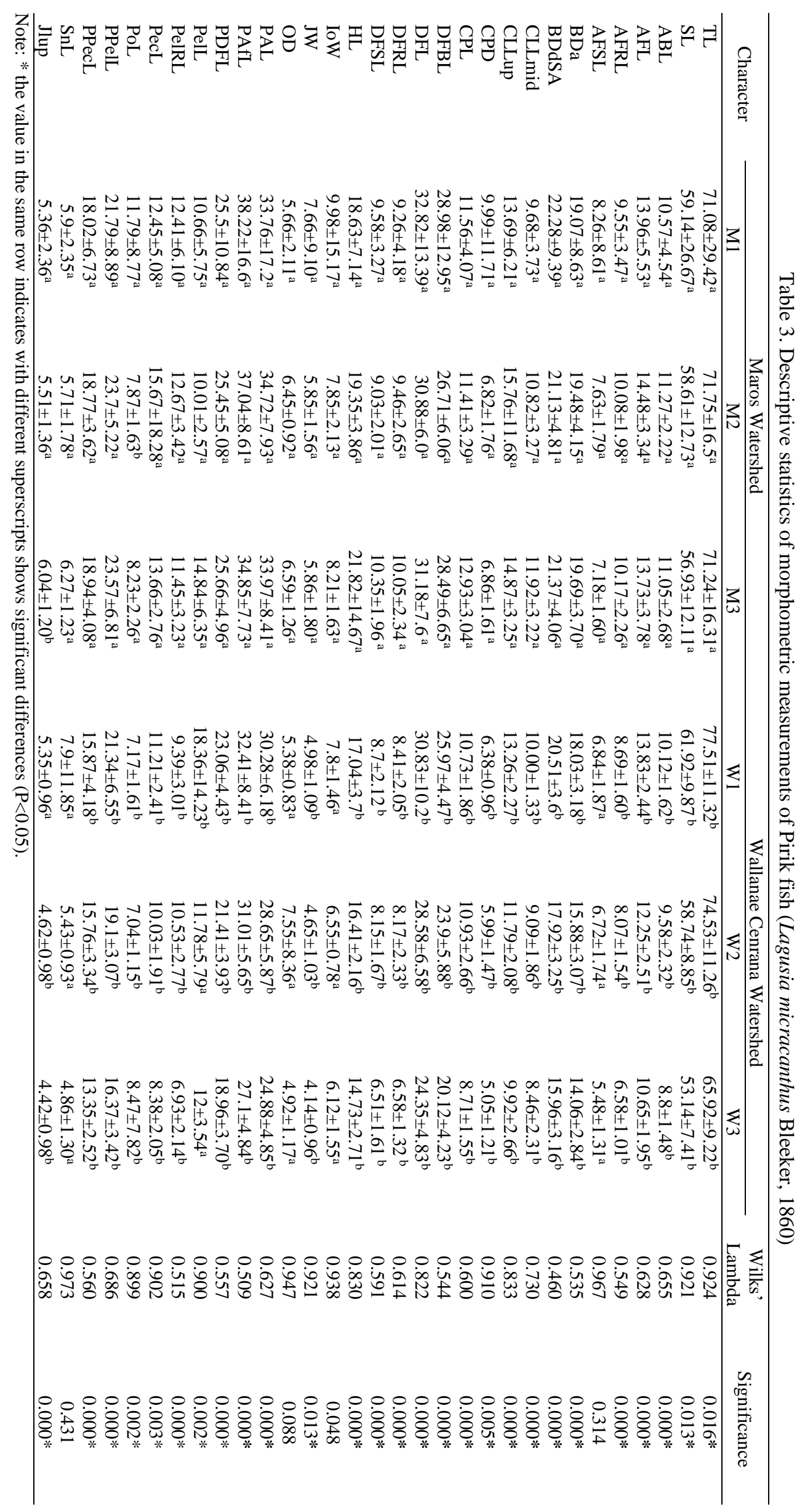


Table 4. Stepwise analysis of morphometric measurements of Pirik (Lagusia micracanthus Bleeker, 1860) in Maros and Walanae Cenranae watersheds

\begin{tabular}{lc}
\hline \multicolumn{1}{c}{ Physical features } & $\begin{array}{c}\text { Special features values } \\
\text { (sorted from highest to lowest values) }\end{array}$ \\
\hline BDdSA (Body depth-dorsal fin origin) & 0.460 \\
PelRL (Pelvic ray length) & 0.294 \\
CLLup (Upper caudal lobe length) & 0.210 \\
SL (Standard length) & 0.147 \\
AFRL (Anal fin ray length) & 0.118 \\
Jlup (Upper-jaw length) & 0.093 \\
CPL (Caudal peduncle length) & 0.079 \\
PAfL (Pre-anal fin length) & 0.069 \\
TL (Total length) & 0.061 \\
ABL (Anal fin base length) & 0.054 \\
HL (Head length) & 0.048 \\
CLLmid (Mid-caudal length) & 0.043 \\
\hline
\end{tabular}

Further analysis is required to obtain the discriminant function of the two analyzed populations of Pirik fish. From this analysis is obtained Wilks' lambda value of 0.43 ( $\mathrm{p}<0.001$ ), which showed the data was appropriate for discriminant analysis, while the eigenvalues obtained were 7.93 and correlation the canonical value of 0.92 indicates that the canonical function is suitable to differentiate the two populations of fish in the Maros watershed and the Walanae Cenranae watershed.

Discriminant analysis of the population for Pirik was divided into two different populations of the Pirik (Figure 4). The Pirik originated from first group is in the positive sector, namely the Maros watershed, which consists of the population of Pirik from Pattunuang River (M1), Bantimurung River (M2) and Pucak River (M3). The second group is classified in the negative sector, namely the population originating from the Walanae Cenranae watershed, namely Camba River (W1), Sanrego River (W2) and Ompo River (W3). The results of the final classification of the second discriminant group of the Pirik population suggests that the Pirik fish population in the Maros watershed, originated from the Pattunuang River (M1) has a 13\% similarity with the Pirik in S.Bantimurung (M2) and 10\% similarity found in Pirik species from Pucak river (M3). The Pirik in Bantimurung river has 3\% similarity with Pirik in Pucak River and 3\% Pattunuang River. The Pirik obtained from Pucak River (M3) has $13 \%$ similarity to Pirik of the Bantimurung River and $10 \%$ to pirik of Pattunuang River. Meanwhile, the pirik in the Walanae Cenranae watershed, the W1 (Camba River) has a $13 \%$ similarity to Pirik of the Sanrego river (M2) and 3\% with Pirik species in the Ompo River. The Pirik in Sanrego River has 13\% similarity with Pirik in the Ompo River and $3 \%$ similarity with Pirik of the Pattunuang River. The Pirik in the Ompo river (M3) has 17\% similarity with Pirik in Camba River and 7\% with Pirik in Sanrego River. In general, the Pirik in Maros watershed does not have identical 
characteristics with the Pirik in rivers of the Walanae Cenranae watershed.

Furthermore, the cluster analysis illustrates that there are two different groups of Pirik fish populations, namely the Maros watershed and the Walanae Cenranae watershed (Figure 5). The Pirik of the Maros watershed is a fish species from the same population. However, Pirik originating from Bantimurung River (M2) and
Pucak River (M3) are the closest kinship compared to Pirik originating from Pattunuang (M1). In the Walanae Cenranae watershed, the population of Pirik is also from the same population, but the Pirik originating from Sanrego River (W2) and W3 Ompo River are the closest kinship compared to Pirik originating from Camba River (W1).

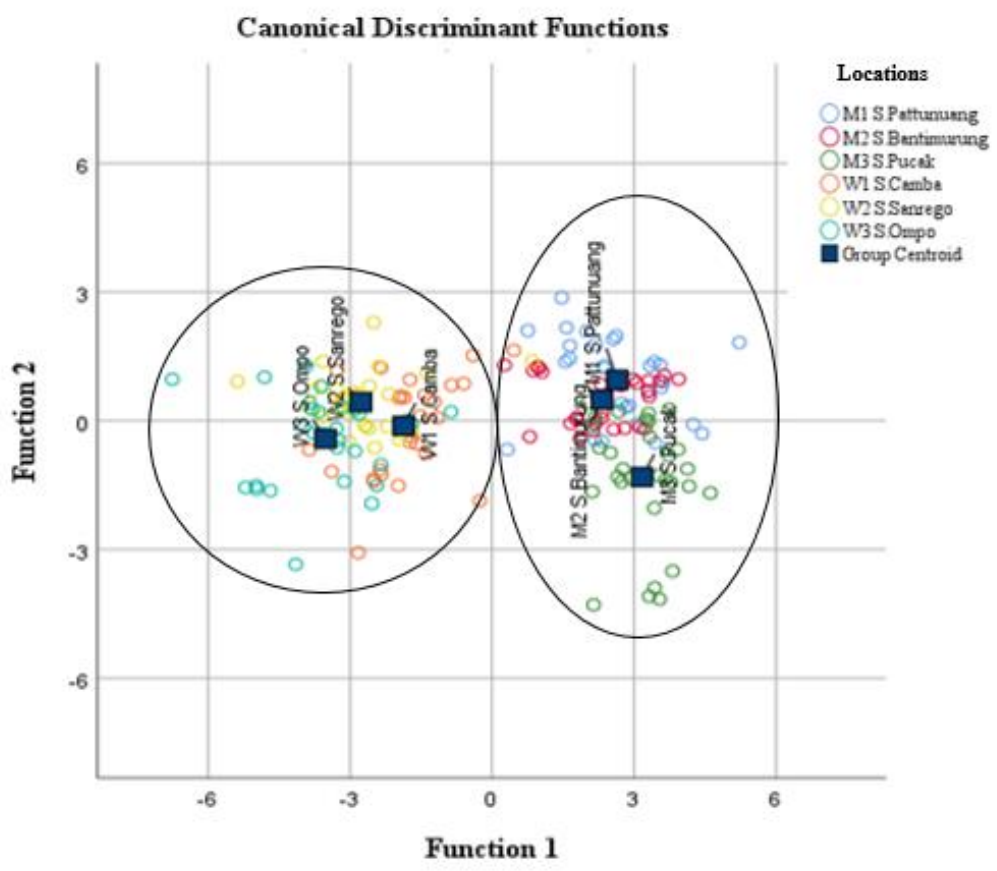

Figure 4. Scatter plot centroid of discriminant analysis of Pirik fish (Lagusia micracanthus Bleeker, 1860) in Maros Watershed and Walanae Cenranae

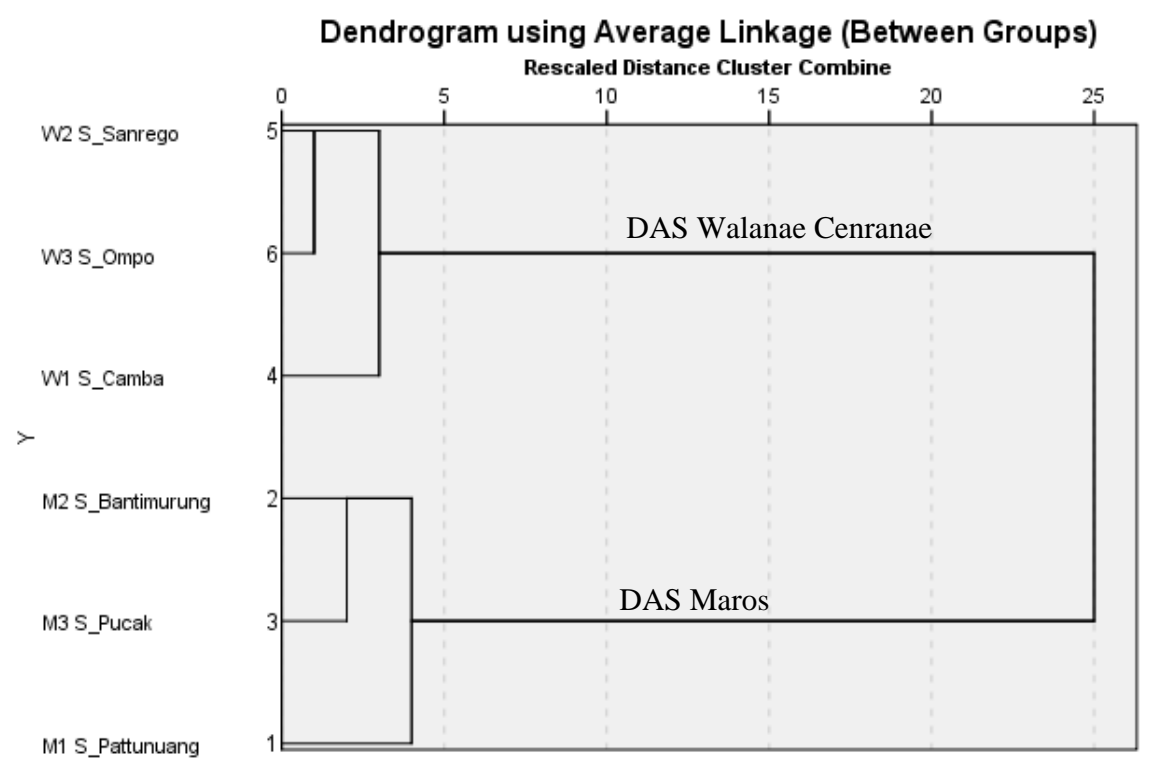


Figure 5. Dendograms are based on cluster analysis of pirik fish (Lagusia micracanthus Bleeker, 1860) in Maros Watershed and Walanae Cenranae

Table 5. Meristic count of pirik fish (L. micracanthus Bleeker, 1860) in the Maros Watershed and Walanae Cendranae Watershed

\begin{tabular}{|c|c|c|c|c|c|c|}
\hline \multirow{2}{*}{ Meristic character } & \multicolumn{3}{|c|}{ Maros Watershed } & \multicolumn{3}{|c|}{ Walanae Cenranae Watershed } \\
\hline & M1 & M2 & M3 & M1 & M2 & M3 \\
\hline Dorsal fin spines and rays (D) & D.XIII. $9^{\mathrm{a}}$ & D.XIII. $9^{\mathrm{a}}$ & D.XIII.9-10a & D.XIII. $9^{\mathrm{a}}$ & D.XIII. $9^{\mathrm{a}}$ & D.XIII.9 ${ }^{\mathrm{a}}$ \\
\hline Anal fin spines and rays (A) & A.III. $8^{\mathrm{a}}$ & A.III. $8^{\mathrm{a}}$ & A.III. $8^{\mathrm{a}}$ & A.III. $8^{\mathrm{a}}$ & A.III. $8^{\mathrm{a}}$ & A.III. $8^{\mathrm{a}}$ \\
\hline Caudal fin spines and rays (C) & C. $16-18^{\mathrm{a}}$ & C. $16-18^{\mathrm{a}}$ & C. $17-18^{\mathrm{a}}$ & C. $16-17^{\mathrm{a}}$ & C. $17-18^{\mathrm{a}}$ & C. $17-18^{\mathrm{a}}$ \\
\hline Ventral fin spines and rays $(\mathrm{V})$ & V.I. $5^{\mathrm{a}}$ & V.I. $5^{\mathrm{a}}$ & V.I. $5^{\mathrm{a}}$ & V.I. $5^{\mathrm{a}}$ & V.I. $5^{\mathrm{a}}$ & V.I. $5^{\mathrm{a}}$ \\
\hline Pectoral fin spines and rays $(\mathrm{P})$ & P. $14-15^{\mathrm{a}}$ & P.14-15 & P. $14-15^{\mathrm{a}}$ & P.15-16 & P. $14-15^{\mathrm{a}}$ & P. $14-15^{\mathrm{a}}$ \\
\hline Lateral line scale (E) & $38-44^{\mathrm{a}}$ & $38-44^{\mathrm{a}}$ & $40-48^{\mathrm{a}}$ & $40-48^{\mathrm{a}}$ & $42-48^{\mathrm{a}}$ & $40-48^{\mathrm{a}}$ \\
\hline Scale above lateral line $(\mathrm{F})$ & $5-6^{\mathrm{a}}$ & $5-6^{a}$ & $5-7^{\mathrm{a}}$ & $6-8^{a}$ & $6-8^{\mathrm{a}}$ & $6-8^{\mathrm{a}}$ \\
\hline Scale below lateral line $(\mathrm{G})$ & $10-12^{\mathrm{a}}$ & $10-12^{\mathrm{a}}$ & $10-12^{\mathrm{a}}$ & $11-22^{\mathrm{a}}$ & $11-14^{\mathrm{a}}$ & $9-12^{\mathrm{a}}$ \\
\hline Scale on the caudal peduncle $(\mathrm{H})$ & $4-7^{\mathrm{a}}$ & $6-8^{\mathrm{a}}$ & $6-8^{\mathrm{a}}$ & $7-8^{\mathrm{a}}$ & $6-9^{\mathrm{a}}$ & $6-8^{\mathrm{a}}$ \\
\hline
\end{tabular}

Note: *), the value in the same row indicates with different superscripts shows significant differences $(\mathrm{P}<0,05)$.

The results of counting fish meristic characters including dorsal fin spines and rays (D), anal fin spines and rays (A), caudal fin spines and rays $(\mathrm{C})$, ventral fin spines and rays $(\mathrm{V})$, pectoral fin spines and rays $(\mathrm{P})$, lateral line scale $(\mathrm{E})$, scale above lateral line $(F)$, scale below lateral line $(\mathrm{G})$ and scale on the caudal peduncle $(\mathrm{H})$ are presented in Table 5.

Table 5 illustrates that the characteristics of the meristic pirik fish showed no significant differences between the population of pirik fish obtained from rivers in Maros watershed and the Walanae Cenranae watershed. Therefore, meristic characters which including dorsal fin spines and rays (D), anal fin spines and rays (A), caudal fin spines and rays $(\mathrm{C})$, ventral fin spines and rays $(\mathrm{V})$, pectoral fin spines and rays $(\mathrm{P})$, lateral line scale $(\mathrm{E})$, the scale above lateral line $(F)$, scale below the lateral line $(G)$ and scale on the caudal peduncle $(\mathrm{H})$ cannot be a distinguishing characteristic of two populations of the pirik fish.

\section{Discussion}

The differences in morphometric characteristics between the population of Pirik in the Maros watershed and in the Walanae Cenranae watershed were confirmed in this present study. The Pirik populations in the Maros watershed consists of fish populations obtained from Pattunuang River (M1), Bantimurung River (M2) and Pucak River (M3) are the same morphometric group. Similarly, the population of Pirik in the Walanae Cenranae watershed consists of fish populations obtained from Camba River (W1), Sanrego River (W2) and Ompo River (W3) are also the same morphometric group. The results showed that the distribution of Pirik population only occurs in habitats in the same watershed. There is no connectivity between pirik population of the Maros watershed with Pirik population of the Walanae Cenranae watershed.

The Maros watershed and the Walanae Cenranae watershed geographically are two separate watersheds which located in different geo- 
graphical areas. The two watersheds are separated or bounded by Kars Mountain, which is located in the Bantimurung-Bulu Saraung National Park, Maros Regency South Sulawesi. The Maros watershed, located in the western part of South Sulawesi, has a lower altitude than the Walanae Cenranae watershed in the eastern part of South Sulawesi. Pirik habitat in Pattunuang River (M1) is at an altitude of 43 masl, M2 Bantimurung River at an altitude of 42 masl and M3 Pucak River at an altitude of 46 masl. Meanwhile, Pirik habitat in Camba River (W1) is at an altitude of 379 masl, Sanrego River (W2) at an altitude of 147 masl and the Ompo River (W3) at an altitude of 88 masl.

The existence of natural geographical barriers, has been contributed to the emergence of differences among fish populations (Palma \& Andrade 2002). The differences in isolated geographical areas, resulting in morphometric and genetic differences. It leads to the absence of gene flow between these populations (Turan \& Ergüden 2004). Isolated habitat conditions have different environments leading to fish populations in these isolated habitats becoming small, mutated, gene flow is interrupted, genetic drift processes and natural selection (Budiharjo 2001).

The differences in the population of Pirik in the Maros and Walanae Cenranae watersheds are characterized by 12 morphometric characters for instances, TL (total length), SL (standard length), BDdSA (body depth-dorsal fin origin), HL (head length), Jlup (upper- jaw length), PAfL (pre-anal fin length), $\mathrm{ABL}$ (Anal fin base length), PelRL (pelvic ray length), AFRL (anal fin ray length), CPL (caudal peduncle length), CLLup (upper caudal lobe length), CLLmid (mid-caudal length). The differences in morphometric characters can be caused by differences in the habitat environment of the Maros and Walanae Cenranae watersheds. Turan et al. (2015) stated that differences in the populations possibly correlate to different habitat characteristics, such as temperature, turbidity, food availability, water depth, and flow velocity.

The average BDdSA (body depth-dorsal fin origin), HL (head length), Jlup (upper-jaw length), PAfL (pre-anal fin length), ABL ( Anal fin base length), PelRL (pelvic ray length), AFRL (anal fin ray length), CPL (caudal peduncle length), CLLup (upper caudal lobe length), CLLmid (mid-caudal length) of Pirik obtained from rivers in the Maros watershed were greater than of the Walanae Cenranae watershed. The degree of variance of morphometric character is highly related to habitat conditions, for instance, food availability and more stable habitat temperatures. This factor is due to canopy cover in riparian zone of the Maros watershed which is better than the Walanae Cenranae watershed which has been degraded due to agricultural activities.The Pirik in Walanae Cenranae watershed characterized based on TL (total length), SL (standard length) which is longer than the Maros watershed. This is closely considered relate to environmental factors, especially water current. The water current in the Walanae Cenranae watershed ranges from 0.1 to $0.8 \mathrm{~m} / \mathrm{s}$ while in the Maros watershed ranges from 0.1 to $1.6 \mathrm{~m} / \mathrm{sec}$. Moreover, the Pirik inhabit the rivers in the Walanae Cenranae watershed has a body shape which more elongated, so that fish will ease to swim and minimize friction with fast flowing water. Hossain et al. (2010) stated that fish species is very sensitive to environmental changes and quickly adapts to morphometric changes as required. 
Several environmental factors consider to alter fish phenotypes or morphology (Vehanen \& Huusko 2011). In the same species, fish size can vary due environmental factors such as temporal variations in the condition of aquatic habitat (Muchlisin 2013), temperature and food abundance (Eyo 2003). Water current is one of the important abiotic factors that affects the morphology of the body (Pakkasmaa \& Piironen 2001; P'aez et al. 2008). The fish inhabits river with high water current tend to have body shape than fish that lives in low water current (Michel et al. 2017). In addition, other factor that may affect fish are fish reproductive and gonad development (Kashefi et al. 2012). According to Swain et al. (1991), the differences in morphological characteristics of fish indicate the high flexibility of a fish species in response to environmental changes.

The characteristics of Pirik including dorsal fin spines and rays, anal fin spines and rays, Caudal fin spines and rays, Ventral fin spines and rays, radius of the pectoral fin, Lateral line scale, Scale above lateral line, Scale below lateral lined and scale on the caudal peduncle are shown in Table 5. This table 5 illustrates that the meristic character does not become a distinguishing feature between the Pirik groups in the Maros and the Walanae Cenranae watersheds, although the two watersheds are known to differ geographically and in their environmental characteristics. Moreover, Smith et al. (2002) revealed that fish characteristic are the result of gene expression, but environmental components can also modify the expression of these genes.

\section{Conclusions}

Pirik in the Maros and Walanae Cenranae watershed are two different population based on morphometric and meristics features. Pirik populations in the those two watersheds are characterized by 12 morphometric characters, including TL (total length), SL (standard length), BDdSA (body depth-dorsal fin origin), HL (head length), Jlup (upper-jaw length), PAfL (pre-anal fin length), ABL (Anal fin base length), PelRL (pelvic ray length), AFRL (anal fin ray length), CPL (caudal peduncle length), CLLup (upper caudal lobe length) and CLLmid (mid-caudal length).

\section{Acknowledgement}

A special thank goes to Syainullah Wahana, Syamsul, Firmansyah Bin Abd Jabbar, Andiara Firdhita AN, Chichilia Qaila AR, who kindly assisted the senior author during the fish sampling, data collection, and handling of samples both in the field and laboratory. Gratitude is also given to the Sulawesi Barat University and IPB University for facilitating this research project. The first author also would like to thank the Ministry of Education and Culture, the Republic of Indonesia for funding this research through the Domestic Postgraduate Scholarship (BPPDN) 2017.

\section{References}

Ahammad AKS, Ahmed MBU, Akhter S, Hossain MDK. 2018. Landmark-based morphometric and meristic analysis in response to characterize the wild Bhagna, Labeo ariza populations for its conservation. Journal of the Bangladesh Agricultural University, 16(1):164-170.

Budiharjo A. 2001. Changes in morphological character of Tawes (Barbodes gonionotus) that live in Serpeng Lake, Gunung Kidul. Biodiversitas, 1(2):104-109.

Eyo JE. 2003. Congeneric discrimination of morphometric characters among members of the pisces genus: Clarias (Clariidae) in Anambra River, Nigeria. The Zoologist, 2(1):1-17. 
Giducos CS, Karim SI, Diamalon AL, Piang MM, Torres MAJ, Requieron EA. 2015. Describing the shape of Sardinella lemuru from Sarangani Bay, Philippines using the landmark-based geometric morphometric analysis. Aquaculture, Aquarium, Conservation \& Legislation Bioflux, 8(6):1072-1080.

Hadiaty RK. 2018. Taxonomy status of endemic icthyofauna in Sulawesi freshwater Sulawesi. Jurnal Iktiologi Indonesia, 18(2):175-190.

Hossain MAR, Nahiduzzaman M, Saha D, Khanam MUH, Alam MS. 2010.Landmarkbased morphometric and meristic variations of the endangered carp, Kalibaus labeo calbasu, from stocks of two isolated rivers, the Jamuna and Halda, and a hatchery. Zoological Studies, 49:556-563

Hubbs CL, Lagler KF. 1974. Fishes of the Great Lakes Region. Univ. Michigan Press, Ann Arbor. 214 pp.

Kashefi P, Bani A, Ebrahimi E. 2012. Morphometric and meristic variations between nonreproductive and reproductive kutum females (Rutilus frisii kutum Kamensky, 1901), in the Southwest Caspian Sea. Italian Journal of Zoology, 79(3):337-343.

Kottelat M, Whitten AJ, Kartikasari SN, Wirjoatmodjo S. 1993. Freshwater Fishes of Western Indonesia and Sulawesi (Ikan Air Tawar Indonesia Bagian Barat dan Sulawesi). Periplus Editions-Proyek EMDI. Jakarta. 377 p.

Michel MJ, Beachum CE, Knouft JH, Chien H, Bennett MG. 2017. Climate change, hydrology, and fish morphology: predictions using phenotype-environment associations. Climatic Change, 140:563-576.

Mojekwu TO, Anumudu CI. 2015. Advanced techniques for morphometric analysis in fish. Journal of Aquaculture Research \& Development, 6(354):1-8.

Muchlisin ZA. 2013. Morphometric variations of rasbora group (pisces: cyprinidae) in Lake Laut Tawar, Aceh Province, Indonesia, based on truss character analysis. Hayati Journal of Biosciences, 20(3): 38-143.

Nath RP, Kundu JK. 2017. Morphometric analysis: a tool to identify green puffer fish Tetraodon fluviatilis (Hamilton, 1822) from the Digha Coastal Region, West Bengal,
East coast of India. International Journal of Zoology Studies, 2(5):203-211.

Omar SBA. 2012. Fish World. Yogyakarta (ID): Gadjah Mada University Press. 478 pp.

P'aez DJ, Hedger R, Bernatcher L, Dodson JJ. 2008. The morphological plastic response to water current velocity varies with age and sexual state in juvenile Atlantic salmon, Salmo salar. Freshwater Biology, 53(8):1544-1554.

Pakkasmaa S, Piironen J. 2001. Water velocity shapes juvenile salmonids. Evolutionary Ecology, 14:721-730.

Palma J, Andrade JP. 2002. Morphological study of Diplodus sargus, Diplodus puntazzo, and Lithognathus mormyrus (Sparidae) in the Eastern Atlantic and Mediterranean Sea. Fisheries Research, 57(2002):1-8.

Parenti LR. 2011. Endemism and conservation of the native freshwater fish fauna of Sulawesi, Indonesia. As cited in: Simanjuntak $\mathrm{CPH}$, Zahid A, Rahardjo MF, Hadiaty KH, Krismono, Haryono, Tjakrawidjaja AH. Prosiding Seminar Nasional Ikan VI \& Kongres Masyarakat Iktiologi Indonesia III. 8-9 Juni 2010. Cibinong, Indonesia. Cibinong (ID): Masyarakat Iktiologi Indonesia. Hlm. 1-10.

Shelley J, Delaval A, Feuvre LM. 2017. A Revision of The Grunter Genus Syncomistes (Teleostei, Terapontidae, Syncomistes) with Descriptions of Seven New Species from The Kimberley Region, Northwestern Australia. Magnolia Press, New Zealand. $103 \mathrm{pp}$.

Siddik MAB, Chaklader MR, Hanif MA, Islam MA, Sharker MR, Rahman M. 2016. Stock identification of critically endangered olive barb, Puntius sarana (Hamilton, 1822) with emphasis on management implications. Journal of Aquaculture Research \& Development, 7(411):1-6.

Smith PJ, McMillan PJ, Bull B, McVeagh SM, Gaffhey PM, Chow S. 2002. Genetic and meristic variation in black and smooth oreos in the New Zealand exclusive economic zone. New Zealand Journal of Marine and Freshwater Research, 36(4):737-750.

Swain SL, Bradley LM, Croft M, Tonkonogy S, Atkins G, Weinberg AD, Huston G. 1991. Helper t-cell subsets: phenotype, function and the role of lymphokines in regulating 
their development. Immunological Reviews, 123(1):115-144.

Turan C, Erguden D, Turan F, Gurlek M. 2004. Genetic and morphologic structure of Liza $a b u$ (Heckel, 1843) populations from the Rivers Orontes, Euphrates and Tigris. Turkish Journal of Veterinary and Animal Sciences, 28(4):729-734.

Turan C, Yalçin S, Turan F, Okur E, Akyurt I. 2005. Morphometric comparisons of African catfish, Clarias gariepinus populations in Turkey. Folia Zoologica, 54(1-2):165-172.

Ukenye EA, Taiwo IA, Anyanwu PE. 2019. Morphological and genetic variation in Tilapia guineensis in West African coastal waters: a mini review. Biotechnology Reports, 24(2019):1-3.
Vari RP, Hadiaty RK. 2012. The endemic Sulawesi fish genus Lagusia (Teleostei: Terapontidae). The Raffles Bulletin of Zoology, 60(1):157-162.

Vari RP, Hutchins JB. 1978. New species of terapon perches (Percoidei, Teraponidae) from Australia. American Museum Novitates, 2654:1-8.

Vari RP. 1978: The Terapon Perches (Percoidei, Teraponidae). A cladistic analysis and taxonomic revision. Bulletin of the American Museum of Natural History, 159(5):175-340.

Vehanen T, Huusko A. 2011. Brown trout Salmo trutta express different morphometrics due to divergence in the rearing environment. Journal of Fish Biology, 79:1167-1181. 